\title{
Interactive control capability, effective organizational learning and firm perfor- mance: An empirical study of milling and metal industry in Tegal
}

\author{
Emiliana Sri Pudjiarti $^{* *}$ and Susetyo Darmanto ${ }^{b}$
}

\begin{tabular}{|c|c|}
\hline CHRON I CLE & A B S TRACT \\
\hline $\begin{array}{l}\text { Article history: } \\
\text { Received: July } 312019 \\
\text { Received in revised format: July } \\
312019 \\
\text { Accepted: September } 16,2019 \\
\text { Available online: } \\
\text { September } 18,2019\end{array}$ & $\begin{array}{l}\text { This study seeks to utilize the theoretical literature and empirical studies of human resource management, re- } \\
\text { sourced based view and management control system to derive the concept of interactive control capabilities, in } \\
\text { an effort to explore the role of effective organizational learning on the capabilities of technological innovation } \\
\text { and company performance. The study places the importance of interactive control capabilities and capabilities } \\
\text { of technological innovation as an important element of company performance. The study was conducted in the } \\
\text { smelting and metalwork industry in Tegal, since Tegal was nicknamed the innovative Indonesian Japanese } \\
\text { whose industries were carried out by skilled hands and simple tools. Amos } 24 \text { software was used as a multivar- }\end{array}$ \\
\hline $\begin{array}{l}\text { Keywords: } \\
\text { Effectively organizational learn- } \\
\text { ing } \\
\text { Interactive control capability } \\
\text { Effective commitment } \\
\text { Technological innovation capa- } \\
\text { bility and firm performance }\end{array}$ & $\begin{array}{l}\text { iate analysis tool to verify the hypothesis. The research findings verify the correlation between effective organ- } \\
\text { izational learning and the capabilities of technological innovation and company performance by mediating in- } \\
\text { teractive control capabilities. Based on the empirical research findings, the recommendations offered are the } \\
\text { concept of interactive control capabilities that play an important role in improving innovative capabilities and } \\
\text { business performance. Technological innovation is one of the drivers and fundamental instruments of growth } \\
\text { strategy. The involvement of top management which is accompanied by the exchange of interactive information } \\
\text { will motivate the learning process in all organizations to avoid uncertainty while ensuring that the information } \\
\text { is not manipulated by subordinates, as well as updating strategies. }\end{array}$ \\
\hline
\end{tabular}

\section{Introduction}

The trade war between the United States of America and China impacts on global uncertainty, because the two countries are the rulers of the world economy today, resulting in chain effects in other countries, and Indonesia is also affected. China as the ruler of the world export market is trying to find new markets, since China has difficulty entering the market in the United States, so China is trying to find the best alternative to sell her products to other countries. This certainly affects stability and balance in the growth of trade and industry in the world market. One sector in Indonesia that was greatly affected by these problems was the smelting and metalwork industry in Tegal, Indonesia. Tegal is the archetype of Japan in Indonesia, because it has the ability to innovate in the smelting industry and metal crafts. Tegal Industry has long been producing various kinds of products such as agricultural equipment, motorbike parts and cars, shipyard dock to metal craft items. All these products are created by creative hands using simple equipment, including raw materials and working at home workshops by skilled hands. But with the global market turbulence threatening incumbent companies, it is evident that many smelters \& metalwork in Tegal are in danger of shutting down (Tempo, August 2, 2015), even companies that have fallen until now are difficult to get back up. Many factors have caused Tegal's smelting and metal craft difficult to compete, one of which is the price factor, because the prices set are more expensive than the prices of similar products imported from China. In terms of product quality, Tegal's metal products are difficult to compete too with products from China that are cheaper. Goods circulating in both the domestic market and markets in Asia are mostly ordered from China.

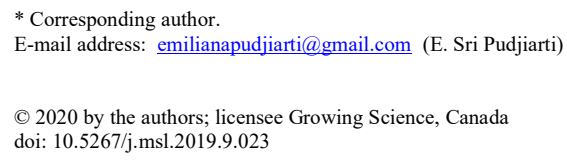


In general, there are important factors that drive turbulence, namely the factors of international competition and information technology factors that have changed the business world faster than ever imagined. Therefore, companies that survive must be oriented to competitiveness and performance as a trigger usually measured by quality, flexibility, resource utilization and innovation. Technology turbulence and intensity of competition require the creativity of the company to always create unique new ideas, then communicate as the company's expertise related to how to obtain, how to interpret, and share knowledge and information to the parties involved both inside and outside the company. All actions have the purpose of modifying behavior.

The general assumption is that organizational learning can facilitate behavioral changes that lead to improved performance and competitiveness. But considering learning is a process of changing cognition and behavior, it is not always followed by changes in performance, so organizational learning is negatively correlated with performance in the short term, and when companies face new unknown operating situations (Crossan et al., 1995). However, it is still believed that organizational learning is an important strategy, as a process by which organizations always learn, especially in a rapidly changing environment. This is the first research gap. A number of studies have long explained that organizational learning is useful for shaping unique knowledge, integration of knowledge and effective use of knowledge (Dibella \& Gould, 1996). Organizational learning is a mechanism that directly affects companies facing turbulence (Baker \& Sinkula, 1990), and can indirectly improve performance (Moorman, 1995). The responsibility of managers in the organizational learning process is to make learning one of the priorities of the organization to build a foundation that can transform individual learning into effective organizational learning. Learning is a market-driven organizational capability (Slater \& Narver, 1995), thus companies operating in turbulent markets, are likely to modify products and markets to adapt to change, and effectively organizational learning leads companies to have the flexibility to adapt to more dynamic changes. Knowledge that accumulates through organizational learning, produces a superior knowledge base, which affects high performance (Curado, 2006). The concept of effective organizational learning is closely related to innovation (Lemon \& Sahota, 2004), and innovation is positively related to culture which emphasizes the formation of adaptive, innovative, and unique knowledge (Hurley \& Hult, 1998). Thus, organizational learning influences innovation activities (Darroch \& McNaughton, 2003). Successful innovation requires companies to carry out planning that must be supported by a structured method, tool, and framework that enables integration between multidisciplinary teams with unique diversity. This situation can give birth to motivation that is very important for conducting research, and to capture the relevance of the management control system to the innovation process. But in many literatures, the role of the management control system on business innovation is still rarely stated clearly and even still ignored (Bisbe \& Otley, 2004). This is the second gap research in this study. We all know that changes in variables in the company's external environment result in internal turbulence that affects the company. Therefore, a broader model is needed to capture management control elements. The results of the study by Bedford et al. (2015) have proven the benefits of management control systems for the innovation process. Management control systems are very important for a company to formulate and implement strategies (Simons, 1991). This reasoning is in accordance with the definition of a management control system, a useful tool for monitoring, and as a formal system and procedure used to maintain information from all activities that have been formulated in the company including the activities of formulating and implementing strategies (Simons, 1990). Therefore, the management control system plays a role in the formulation of strategies. This is stated by Chapman (1998) that basically the management control system follows a process that involves managers in various discussions and interactions. Simons et al. (2000) introduced four forms of management control systems called levers of control, namely system beliefs, boundary systems, diagnostic control systems, and interactive control systems. Some research results such as Abernethy and Brownell (1999) on the object of budget formulation use an interactive style, while Tuomela (2005) uses diagnostic and interactive controls. Other researchers such as Widener (2007) state that Levers of Control are associated with organizational learning, while the interactive control systems have positive and significant effects on the capability of the company. These results indicate that interactive control has a positive effect on company capability because the organization carries out dialogue, stimulates creativity of the organizational members, and focuses the attention to the organization. This result is in accordance with what was stated by Simons (1990) that the formal management control system facilitates organizational learning so that it becomes effective.

An approach that is often applied by companies to deal with external environmental turbulence is the resources-based view (RBV) approach. The basic assumption of the RBV theory is that capability is the main source for achieving sustainable competitive advantage (Barney, 1991). According to Peteraf and Barney (2003), capability lifecycle is a new concept that comprehensively explains the general pattern of development of organizational capabilities based on a dynamic resourcebased theoretical approach from time to time. The RBV concept relies heavily on unique, valuable, and difficult-to-replicate resources and capabilities in an effort to create competitive advantage. Based on the RBV approach and management control system (MSC), the new concept model proposed in this study is interactive control capability. The results of the study by Widener (2007) have examined the relationship between organizational learning and interactive control systems that have found positive and significant relationships. Henri (2006) also examined the same thing which has also found that there is a positive relationship between interactive performance measurement systems that are part of the management control system and organizational learning. Several other studies have also explained that interactive control systems have meaningful consequences for business organizations such as idea generation for product development and cost reduction (Tani, 1995), competitive adaptation (Osborn, 1998), strategic change (Abernethy \& Brownell, 1999) and successful product innovation (Bisbe $\&$ Otley, 2004). Based on the background of the problems mentioned above, the formulation of the research problem proposed is how the relationship of effective organizational learning to improve firm performance is mediated by interactive control 
capability and technological innovation capability and effective commitment. This study was conducted in Tegal which has a smelting and metal craft industry, considering that Tegal was the archetype of Japan in terms of innovations, but currently experiencing a decline in business.

\section{Literature review and hypothesis development}

This study uses three approaches, namely RBV, human resource management (HRM) and MCS. The RBV's format illustrates the ability of a company to have an advantage that is difficult to emulate or create by competitors, these advantages can create obstacles for competitors (Mahoney \& Pandian, 1992). A number of frameworks of RBV theory provide views on core competencies (Hamel \& Prahalad, 1990), views on dynamic capabilities (Helfat \& Peteraf, 2003), and knowledge-based views (Grant, 1998). Thus, the RBV looks at different but interconnected characteristics between individuals and organizational factors to achieve a source of competitive advantage (Welsh et al., 2011). Company resources and capabilities are important factors in business strategy. The second approach is the theory of HRM where the emphasis is on the knowledge and skills possessed by individuals, both entrepreneurs and employees (Davidsson \& Honig, 2003). The third approach using the theory of management control systems (MCS), is a system used to plan various activities to realize the vision of the organization through a mission that has been decided. MCS is used to implement and control the implementation of planning activities. Management control systems are very important, because to achieve company goals, various problems arise due to lack of direction from managers or section leaders, lack of motivation, and the existence of individual limitations, the management control system serves to direct and control the implementation of planned activities according to the objectives expected. Simons et al. (2000) explained that there are four types of MCS called Levers of Control (LOC), namely, belief systems, boundary systems, diagnostic control systems, and interactive control systems, all of which are useful for companies in achieving goals because they can direct employee behavior. Belief system explains about the core values of the organization, the boundary system explains what cannot be done, diagnostic control system describes motivating employees and harmonizes employee behaviors with organizational goals, and provides a monitoring mechanism, while the interactive control system describes a two-way communication process between managers and subordinates at various levels of the organization. The elaboration of the three RBV, HRM and MCS approaches reduced a new concept called interactive control capability.

The concept of interactive control capability describes the management style formally and the management control system, in which top managers use it formally to engage regularly and personally in the operational decisions of operations managers. With interactive measurement, it will trigger company members to develop future plans so that they can create maximum performance (Simons, 1994b). This statement is reinforced by Bisbe and Otley (2004) who found that the use of interactive controls can encourage companies to improve performance firms. This finding is also reinforced by the results of research conducted by Naranjo-Gil and Hartmann (2007), namely that the use of interactive control measures can improve performance through changing strategies.

\section{$\mathrm{H}_{1}$ : Interactive control capabilities has a positive effect on performance firms.}

According to Marquarnt (1996), organizational learning is a process in which individuals gain new knowledge and insights to change the behavior and actions of organizational members. Organizational learning means the process of improving action through better knowledge and understanding (Adel Ismail et al., 2007). Kloot (1997) says that organizational learning is one of the processes of identifying problems, the process of determining the best solution, and how companies can quickly respond to changes in the business environment which will ultimately affect the improvement of performance firms. Effective organizational learning using the constructivism theory proposed by Grant Keeble (2009) which assumes that individuals are not passive recipients of information, but actively participate in the learning process and in constructing the meaning of information around it. This means that knowledge is built in the minds of individuals. If new knowledge is able to answer the problems faced, then the new knowledge will be stored in the long-term memory. Effective organizational learning is a good way to find out the individual mindset of how to be able to understand and solve problems well. Shurafa and Mohamed (2016) and Tippins and Sohi (2003) reveal that organizational learning is positively related to performance. Simons et al. (2000) explained that there are two possible reasons for top managers to use control interactively. First, to look for and learn and that is a fundamental assumption behind interactive control to improve organizational performance through strategy updates and that has a significant influence on generating and sharing information, which in turn will produce the desired knowledge and experience. The involvement of top management accompanied by the exchange of interactive information will motivate and facilitate the learning process throughout the organization. Secondly, interactive control by top managers in some cases for uncertainty avoidance and to ensure that the information is not manipulated by subordinates and at the same time performs strategy updates.

\section{$\mathrm{H}_{2}$ : Effective organizational learning has positive effect on performance firms.}

Some empirical evidence has proven the relationship between organizational learning and the ability of technological and performance innovations. Song and Calantone (2005) found that effective organizational learning dynamically configures and applies innovation results to respond to customer changing needs. Similarly, Fiol and Lyles (1985) state that high organizational learning is considered capable of supporting the success of technological innovations that pay attention to changes in knowledge and involve the acquisition of knowledge, dissemination, improvement, manufacture and implementation. Thus, 
through effective organizational learning, it will trigger to create new innovations for employees, and with innovation, it will improve company performance and opportunities to achieve competitive advantage (García-López et al., 2010).

$\mathrm{H}_{3}$ : Effectiveness of organizational learning has a positive effect on a technological innovation capability.

Interactive control capability is part of management control aimed at the ability of the organization to facilitate the implementation of the strategy. Interactive control is a management control system today to determine tomorrow's strategy. Interactive concepts are used carefully to company information from top managers continuously to corporate strategy, where managers actively and regularly involve themselves in decision making and employee activities (Bisbe \& Otley, 2004). One inherent characteristic of interactive control is to determine tomorrow's strategy, with the main goal of facilitating the creation of learning organizations reminding management of strategic uncertainties in the form of problems or opportunities (Grafton et al., 2010). Thus, with the use of interactive supervision, companies can see and look for opportunities by conducting dialogue and debate and monitoring competition risk to capture new strategy opportunities in determining the position of the company on the market. The relationship between effective organizational learning and the concept of interactive control capability can be explained in that effective organizational learning relates to strategies in adjusting the market environment to compete in the long run. Technological innovation is one of the drivers and fundamental instruments of growth strategy (Azubuike, 2013).

\section{$\mathrm{H}_{4}$ : Effective organizational learning has a positive effect on interactive control capabilities.}

Technological innovation designates the ability of an organization to choose, spread, and then improve technology (Yam et al., 2004), emphasizing that technological innovation is a skill involved in realizing and supporting the company's technological innovation strategy. Thus, technological innovation is the process of accumulating progressive experiences including the use of technology, improvement and application of existing technologies. Archibugi and Coco (2005) show that technological innovation is the ability to access and digest external knowledge into several unique skills or knowledge, then use it dynamically to improve or develop new products and launch them successfully. Yam et al. (2004) also commented that technological innovation is a combination of techniques of knowledge and management skills from various fields, that by strengthening these fields, companies can build competitiveness of their organizations. In the study, Archibugi and Coco (2005) proposed six dimensions to measure technological innovation capabilities which include: technology learning, R \& D, resource allocation, manufacturing capability, marketing skills, organizational skills in developing strategies. Some empirical evidence has proven the relationship between technological innovation and business performance such as Walsh and Linton (2002) who emphasize the study of technological innovation as a unique technique or manufacturing process owned by a company, which enables it to react quickly to changes in the environment. Parkman et al. (2012) have examined the relationship of firm performance with innovation, finding also that the company's tendency towards innovation is very important in the competitive environment to obtain a higher competitive advantage. Innovative organizations have the ability to increase competitive advantage (Liao \& Wu, 2010).

\section{$\mathrm{H}_{5}$ : Technological innovation capability has a positive effect on firm performance.}

The focus of interactive control attention is on organizations that faces strategic uncertainty, as stated by Simons (1994a) that interactive control is an important process to trigger innovation, because it is able to motivate company members to look for business opportunities. Research by Bisbe \& Otley (2004) has also explained that interactive control systems have meaningful consequences for various organizational outcomes such as idea generation for product development and cost reduction (Tani, 1995), strategic change (Abernethy \& Brownell, 1999) and product innovation successful. Similarly, the study by Azubuike (2013) found a relationship between company technological innovation and its performance in developing new products. Suurs (2009) emphasizes that the technological innovation approach focuses on system dynamics. The focus on entrepreneurial action can encourage experts to consider technological innovation as something that must be built over time. Carlsson and Stankiewicz (1991) show that the Technology Innovation System is defined in terms of the flow of knowledge / competence rather than the flow of ordinary goods and services. They consist of a network of dynamic knowledge and competencies.

$\mathrm{H}_{6}$ : Interactive control capability has a positive effect on a technological innovation capability.

Meyer and Allen (1990) identified three components of commitment, namely: affective commitment, ongoing commitment, and normative commitment. The general point of the component of organizational commitment is that individuals continue to do and will stay in whatever organization they feel both positive and negative feelings. An individual who has a strong affective commitment to work in an organization because they really want it. These individuals form a positive image of their organization, and assume that their organization is a "true organization". The individual also feels proud of his organization because he can develop his self-esteem, form affective ties with the organization, and make better efforts. Individuals who are committed to the organization work more compatible, productive, and loyal. According to Allen and Meyer (1990) there are four antecedent variables that affect affective commitment, namely: personal characteristics, job characteristics, work experience and structural characteristics. Work experience variables are declared most effective for creating affective commitment, because psychologically employees feel comfortable and competent in the organization. Organizational reliability, openness to new ideas, equality, roles and clarity aim to meet the needs for employees to feel comfortable feelings. On the other hand, 
challenging work, feedback made by management and participation in decision making make people feel competent. Employees are emotionally committed to the organization if they feel competent and comfortable in the workplace. Meyer et al. (2006) also explain that individuals, who are bound to the organization emotionally, will have higher performance. The research results by Chen and Sun (2009) show that there is a positive relationship between affective commitment and work performance. Once employee satisfaction increases, it will improve performance. A company in the face of tight business competition is very dependent on individuals who are in it who have speed, responsiveness, agility, and ability to deal with uncertainty. Strategies used to quickly respond to and adapt to change by building "Learning Organizations". According to Marquarnt (1996), organizations will be able to become learning organizations only by teaching individuals in them by empowering 5 aspects, namely learning, organization, people, knowledge and technology. As an organization that learns always provides opportunities for employees to always be able to improve themselves to achieve success. High commitment from each individual can be identified from involvement in the organization and feel comfortable as a member of the organization (Jong-Wook et al., 1997). A high level of commitment to the organization will affect the desire of employees to remain in the organization, have a close emotional closeness to the organization. This means that the individual will have motivation and desire to contribute meaningfully to the organization compared with individuals with lower commitments and at a certain level will in turn affect the actual performance of employees (Mowday et al., 1982). Furthermore, creative individuals are individuals who have certain characteristics that always process dynamically in their behavior in the form of cognition and affection skills. Cognitive skills in the form of ability to think fluently (sparking lots of ideas, answers, problem solving, or questions), flexible thinking skills (generating ideas, answers, or various questions, and can see a problem from a different perspective), original thinking skills (generating new, unique and original expressions), skills of detailing and elaborating (developing, enriching, or working the details of an idea so that it becomes more interesting), and assessing / evaluating skills (determining one's own judgment and determining whether a question, a plan, or an action is wise or not).

$\mathrm{H}_{7}$ : Effective organizational learning influences on effective commitment.

$\mathrm{H}_{8}$ : Effective commitment influences on individual performance.

\section{Research method}

This study uses primary data obtained through questionnaires using google drive compiled through whatsApps to smelter artisans and metal casting in Tegal. The reason why Tegal was determined as an object was because in Tegal there were many metal craftsmen with various types of products. The number of samples was 200 artisans. However, since many respondents were inconsistent in giving answers, only 216 units of observation were declared fit and determined by purposive random sampling technique. Variable measurements using a 1 Likert scale up to 10, Strongly Disagree $=1$, and Strongly Agree $=10$. Measurement of effective organizational learning consists of 4 indicators, namely: a). formation of unique knowledge; b) knowledge integration; c) expansion of holistic knowledge; d) effective use of knowledge. Technology Innovation Success Variable (Archibugi \& Coco, 2005) consists of 6 indicators, namely: a) learning of technology; b). research and development; c) allocation of resources; d) manufacturing capability; e). marketing skills; and f). Organizational skills in strategizing. Interactive control capability variables (Simons et al., 2000) and RBV from Barney( 1991) consist of 5 indicators, namely: The ability to a). develop discussions in meetings with superiors, subordinates and colleagues; b). develop challenges and debates based on data, assumptions and action plans; c). provide a general view of the organization; d). lay the foundation of commitment to the organization; e) Focus on the main problem. Measurement of effective commitment refers to the work of Kaptijn (2009), with 4 indicators, namely: a). Affective commitment work, b). Affective commitment team, c). Affective commitment colleagues d). Affective commitment business. Measurement of Firm's performance refers from Lee and Miller (1996), with 6 indicators, namely: a) sales growth; b) revenue growth; c). growth of market share, d). asset growth, e).new product development, and f). employee morale and employee welfare. Furthermore, the hypotheses testing was done using structural equation modeling as a tool to test the relationships between complex variables and obtain a comprehensive picture of the overall model.

\section{Results and discussion}

\subsection{Dimension Analysis, Reliability, and Validity}

EFA is a method of factor analysis to identify the relationship between manifest variables or indicator variables in constructing a construct. The results of the Kaiser Meyer Olkin test stated that it must be greater than 0.60 and significant. A measure indicating that an indicator entered into a particular indicator in the EFA is the value of the loading factor. When the factor value loads a larger indicator against one particular factor, then the indicator can be grouped into these factors (Table 1). Regarding convergent validity, it was found that all indicators showed significant factor loading $(\mathrm{p}<0.01)$. Reliability of all latent variables higher than 0.7, values considered adequate by Hair et al. (1998). Similarly, EVA values are higher than 0.5. Furthermore, testing data validity is used to determine the extent to which the accuracy and accuracy of a measurement instrument in performing its measuring function, so that the data can be relevant to the purpose of measurement. In contrast, reliability shows how much the degree of test consistently measures the measured target. 
Table 1

Data Instrument Test

\begin{tabular}{|c|c|c|c|c|}
\hline Variable \& indicator & Loading & $\begin{array}{r}\text { Reliability } \\
\text { Construct }\end{array}$ & $\begin{array}{c}\text { Variance } \\
\text { Extract }\end{array}$ & $\begin{array}{l}\text { Validity } \\
\text { Indicator }\end{array}$ \\
\hline Effectively organizational learning & - & \multirow{5}{*}{0.800} & \multirow{5}{*}{0.501} & \\
\hline 1. Formation of unique knowledge & 0.698 & & & 0.616 \\
\hline 2. knowledge integration & 0.699 & & & 0.596 \\
\hline 3. Expansion of holistic knowledge & 0.724 & & & 0.621 \\
\hline 4. Effective use of knowledge & 0.709 & & & 0.624 \\
\hline \multicolumn{5}{|l|}{ Technology Innovation Success } \\
\hline Learning of technology & 0.675 & \multirow{5}{*}{0.845} & \multirow{5}{*}{0.522} & 0.615 \\
\hline 2. Research and development & 0.723 & & & 0.715 \\
\hline Allocation of resources & 0.747 & & & 0.647 \\
\hline Manufacturing capability & 0.737 & & & 0.694 \\
\hline 5. Marketing skill & 0.730 & & & 0.646 \\
\hline \multicolumn{5}{|l|}{ Interactive control capability } \\
\hline 1. The ability to develop discussions in meetings with & 0.784 & \multirow{5}{*}{0.827} & \multirow{5}{*}{0.545} & 0.621 \\
\hline 2. The ability to develop challenges and debates based on & 0.765 & & & 0.657 \\
\hline 3. Provide a general view of the organization & 0.711 & & & 0.674 \\
\hline 4. Lay the foundation of commitment to the organization & 0.690 & & & 0.658 \\
\hline 5. Focus on the main problem & 2.950 & & & 0.653 \\
\hline \multicolumn{5}{|l|}{ Effective commitment } \\
\hline 1. Affective commitment work, & 0.716 & \multirow{4}{*}{0.838} & \multirow{4}{*}{0.565} & 0.645 \\
\hline 2. Affective commitment team & 0.787 & & & 0.681 \\
\hline 3. Affective commitment colleagues & 0.710 & & & 0.645 \\
\hline 4. Affective commitment bussiness. & 0.791 & & & 0.702 \\
\hline \multicolumn{5}{|l|}{ Firm's performance } \\
\hline 1. Sales growth & 0.705 & \multirow{5}{*}{0.838} & \multirow{5}{*}{0.565} & 0.622 \\
\hline 2. Revenue growth & 0.739 & & & 0.660 \\
\hline 3. Market share growth & 0.753 & & & 0.688 \\
\hline 4. Asset growth, & 0.742 & & & 0.678 \\
\hline 5. new product development & 0.685 & & & 0.647 \\
\hline
\end{tabular}

\subsection{Respondent Demographic Characteristic}

Empirical data found several things related to the demography of the respondents, where the majority is male (84.04\%). Their age is very productive and mature, seen at the age of 30 years $(80.20 \%)$. Most of the education background is first and secondary elementary school (75.26\%), although some have already received higher education. 76.53\% of business experience has run its business for more than 15 years in the business of metal smelting and smelting in Tegal.

\subsection{Goodness of Fit Model}

According to Joreskog and Sorbom to test the SEM model, it was conducted through a 2-stage approach, namely the test of individual and simultaneous measurement models. Statistics test individually using the t test, through the output of the statistical path diagram $t$-values. Then the $t$ test results are confirmed with a test error rate of 0.05 . If the test results show significant, then $\mathrm{t}$-value $<0.05$. Furthermore, the overall fit test model in SEM is a match between the sample covariance matrix and the estimated population covariance matrix produced, in general it can be explained that the diversity that exists in repressive samples with population diversity.

Table 2

Goodness of Fit Model

\begin{tabular}{|c|c|c|c|}
\hline Criteria of Fit & Cut of value & Result & Remark \\
\hline \multicolumn{4}{|l|}{ Absolute Fit Test } \\
\hline 1. Chi-Square & $<236.16$ & 252.747 & Fit \\
\hline 2. P-value & $>0.05$ & 0.084 & Fit \\
\hline 3. Goodness of Fit Index(GFI) & $>0.90$ & 0.909 & Fit \\
\hline 4. Root Mean Square Error of Approximation (RMSEA) & $<0.08$ & 0.025 & Fit \\
\hline \multicolumn{4}{|l|}{ Incremental Fit Measures } \\
\hline 1. Ajusted GFI (AGFI) & $>0.90$ & 0.888 & Marginal \\
\hline 2. Normed Fit Index (NFI) & $>0.90$ & 0.902 & Fit \\
\hline 3. Comparative Fit Index (CFI) & $>0.90$ & 0.985 & Fit \\
\hline 4. Incremental Fit Index (IFI) & $>0.90$ & 0.990 & Fit \\
\hline 5. Relative Fit Index (RFI) & $>0.90$ & 0.886 & Fit \\
\hline 6. Tucker-Lewis Index & $>0.90$ & 0.983 & Fit \\
\hline \multicolumn{4}{|l|}{ Parsimonius Fit Measures } \\
\hline 1. Parsimonious Normed Fit Index (PNFI) & $>0.90$ & 0.807 & Fit \\
\hline 2. Parsimonious GFI (PGFI) & $>0.90$ & 0.921 & Fit \\
\hline 3. Akaike Information Criterion (AIC) & approaching 0 & 0.00539 & Fit \\
\hline
\end{tabular}


Based on Table 2, it can be concluded that the resulting pathway model is declared fit because it is in the required cut of value range. Similarly, testing SEM assumptions, that data has been declared normal in both the multivariate and univariate dimensions, the data is also free from data outliers both multivariate and univariate, as well as data also free from multicollinearity and singularity.

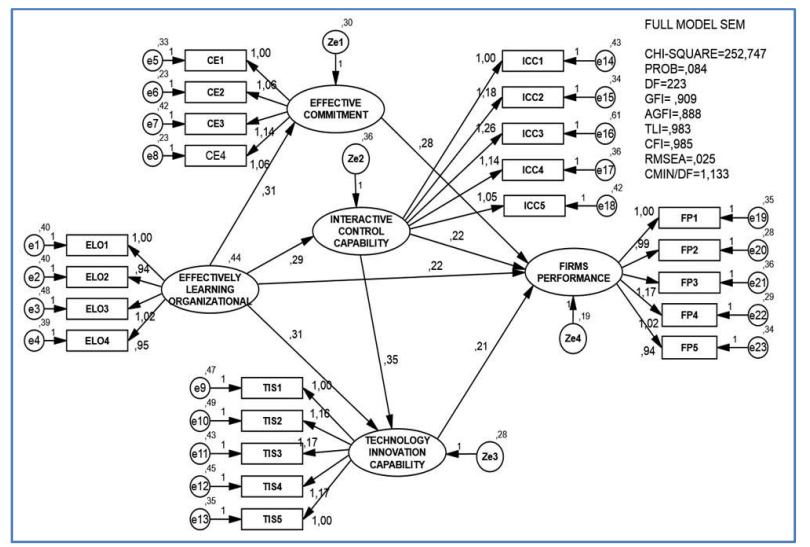

Fig. 1. Full Model SEM Interactive Control Capability (Source: Author’s own work in 2019)

\subsection{Hypothesis Testing}

The testing of Hypothesis 8 is shown in Table 3.

Table 3

$\underline{\text { Regression Weights }}$

\begin{tabular}{|c|c|c|c|c|c|c|c|}
\hline & Causa & & Estimate & $\begin{array}{c}\text { Standardized } \\
\text { Estimate }\end{array}$ & S.E. & C.R. & $\mathrm{P}$ \\
\hline Interactive Control Capability & $\rightarrow$ & Firm Performance & .219 & .235 & .075 & 2.916 & .004 \\
\hline Effectively Learning Organizational & $\rightarrow$ & Firm Performance & .215 & .243 & .077 & 2.801 & .005 \\
\hline Effectively Learning Organizational & $\rightarrow$ & Technological Innovation Capability & .307 & .322 & .080 & 3.865 & $* * *$ \\
\hline Technological Innovation Capability & $\rightarrow$ & Firms Performance & .211 & .227 & .079 & 2.679 & .007 \\
\hline Interactive Control Capability & $\rightarrow$ & Technology Innovation Capability & .345 & .344 & .083 & 4.183 & $* * *$ \\
\hline Effectively Learning Organizational & $\rightarrow$ & Effective Commitment & .308 & .351 & .077 & 3.976 & $* * *$ \\
\hline Effective Commitment & $\rightarrow$ & Firm Performance & .279 & .276 & .078 & 3.567 & $* * *$ \\
\hline Effectively Learning Organizational & $\rightarrow$ & Interactive Control Capability & .294 & .310 & .082 & 3.571 & $* * *$ \\
\hline Effectively Learning Organizational & $\rightarrow$ & Interactive Control Capability & .294 & .310 & .082 & 3.571 & $* * *$ \\
\hline
\end{tabular}

Source : Author's own work (2019)

The first hypothesis, i.e. the effect of effective learning organizational on interactive control capability, is proved to be significant with CR 3.571 when the level of significance is five percent. This study explains that the existence of environmental changes results in increased uncertainty which means increasing the need for companies to learn various things in different ways. Therefore, effective organizational learning will result in a broader value of analysis (Zhang \& McCullough, 2002). As stated by Widener (2007), there is a positive and significant relationship between organizational learning concepts and interactive control systems. There are several reasons why managers use the interactive control system, namely 1) the economy, management attention is a scarce and expensive resource; 2) cognitive, the ability of each individual to process large amounts of information is limited; and 3) strategic, related to active learning about strategy uncertainty and collecting new action plans (Simons et al., 2000). The second hypothesis, i.e. Effective Learning Organizational influences the Effective Commitment, is proved significant with CR 3.976 when the level of significance is five percent. This study supports the work of Jong-Wook et al. (1997). Through individual learning, everything can never be done before. To create individual learners by providing the widest opportunity for employees to always Up Date knowledge. This can be marked by a commitment to present something beyond mere loyalty to an organization and willingness to provide something to help the success of the organization. The main purpose of organizational learning is to improve the quality of performance and quantity that increases sales, achieves a lot of support, creates, maintains, and enlarges the customer base. Furthermore, organizations that learn quickly are able to enhance strategic capabilities, enabling them to maintain positions of competitive advantage and in improving their results. The organizational learning attitude, behavior, and strategy are guidelines for long-term organizational performance. In addition, future performance will be the product of the current learning process. The third hypothesis, i.e. Effective Learning Organizational influences on Technological Innovation Capability, is proved significant with CR 3.865 when the level of significance is five percent. This study supports (Burgelman et al., 2004) arguing that technological innovation refers to the ability of an organization to choose, spread, and then improves technology, likewise (Yam et al., 2004) emphasizes that technological innovation is the skill of individuals involved in realizing and supporting the company's technological innovation strategy. Thus, technological innovation is the process of accumulating progressive experiences including the use of technol- 
ogy, improvement and application of existing technologies. The ability to realize innovation and spread knowledge to companies is obtained through organizational learning. This is as stated by Argyris and Schön (1978), that organizational learning is a circle of individual activities to find a problem (discovery), try to make a solution (invention), produce and implement solutions (production), and evaluate the results obtained to deliver it to new problems (evaluation). The fourth hypothesis, i.e. the effect of Interactive Control Capability on Technological Innovation Capability, is proved to be significant with CR 4.183 when the level of significance is five percent. Interactive control is not a unique type of control system (Simons, 2000). Each control system can be used interactively by senior managers if the system matches the level of uncertainty required (Simons et al., 2000). Whereas Simon's choice of interactive control is very dependent on four factors, namely 1) technology dependence, 2) regulation, 3) complexity of value creation, and 4) reality of tactical response. The technological innovation' ability is to access and digest external knowledge into several unique skills or knowledge, then use it dynamically to improve or develop new products and launch them successfully. This ability is an accumulation of progressive experiences including the use of technology, improvement and application of existing technologies (Archibugi \& Coco, 2005), all of which are used to streamline strategic action plans in the face of uncertainty, according to Widener (2007) through Lever's concept of explaining that the system control has a positive effect on a company's capability because the organization carries out dialogue, stimulates the creativity of organizational members, and focuses on the attention of the organization. Therefore, technological innovation plays an important role, as stated by McAdam et al. (2004) that the company's tendency towards innovation is very important in the competitive environment to obtain a higher competitive advantage. The fifth hypothesis, i.e. the effect of Technological Innovation Capability on Firms Performance, is proved to be significant with CR 2.679 when the level of significance is five percent. This study supports Walsh and Linton (2002) who emphasize the study of technological innovation as a unique technique or manufacturing process owned by a company, which enables it to react quickly to changes in the environment. Technological innovation is one of the drivers and fundamental instruments of growth strategy. McAdam and Keogh (2004), investigated the relationship between firm performance relationship innovation and found that the company's tendency towards innovation is very important in the competitive environment to obtain a higher competitive advantage (Parkman et al., 2012). Innovative organizations have the ability to increase competitive advantage (Liao \& Wu, 2010). Competition in the business world is getting higher nowadays. Companies must be able to develop and create new values or innovations to be able to survive in competition. The phrases "Innovate now or pay later" or "innovate or evaporate" have been voiced by managers experienced in the field of business. Companies that experience difficulties, such as a decline in performance in general, are companies that are in the status quo because of past successes. However, at the turn of the $21^{\text {st }}$ century, the rate of competitiveness is getting steeper. The lifecycle of a product is only a matter of months, instead of years (Wirasasmita, 2010). The sixth hypothesis, i.e. the effect of Interactive Control Capability on Firms Performance, proved significant with CR 2.916 when the level of significance is one percent. This study supports Naranjo-Gil and Hartmann (2007), that the use of interactive control measures can improve performance through changing strategies. By using an interactive control system that serves to monitor or oversee strategic uncertainties, top management will reveal the value they have and their references to individual organizations that provide input to the decision-making process. Observation or supervision is an action to look for things that happen unexpectedly, and interactive management controls will provide guidance to members of the organization who look for things that are beyond expectations and what kind of intelligence information will be collected (Simons, 1990). Things that happen beyond expectations are likely to become new alternatives, new preferences, or changes for the company. Taking a new alternative decision by top managers is crucial when the decision is related to strategic policy and the company resources. The interactive control system can control and enable top managers to have full information about decisions taken and distributed across all company lines. The ability to develop insight, knowledge, and dialogue on past activities is also used to anticipate the future. The seventh hypothesis testing, i.e. Effective Learning Organizational influences on Firm Performance is proved to be significant with CR 2.801 when the level of significance is one percent. This study supports the results of the previous studies that Effective Learning Organizational was a key factor to maintain company sustainability (Ireland et al., 2001). In other words, the more intensive the organization conducts learning, the more likely the company will be able to reach a level of long-term competition and ultimately become more superior than the competitors (Ordóñez de Pablos \& Lytras, 2008). So basically, all organizations are learning, either consciously or unconsciously as a basic requirement to maintain existence, so that learning organizations are needed for management to develop sustainable organizational capacity to adjust and make changes (Robbins, 2009). Thus, learning is a fundamental process that is relevant to many aspects of organizational behavior, and is a relatively permanent behavior change that occurs as a result of experience. The eighth hypothesis, i.e. the effect of the Effective Commitment influences on Firm Performance, is proved to be significant with CR 3.567 when the level of significance is five percent. This study supports Mowday et al. (1982) that high commitment from each individual can be identified from involvement in the organization and comfortable feeling as a member of the organization, meaning that the individual has the motivation and desire to contribute to the organization which in turn affects the employee's actual performance. Meyer et al. (2006) claimed commitment from managers is very important to improve the ability to identify and utilize sources of uniqueness, creative human resources, and other aspects to achieve success in business.

\section{Conclusion}

There are so many business risks that cause a company not to survive, one of the biggest risks is a change that causes uncertainty, since the change in business is fast, both in terms of market, competition, and technology. Changes that occur are fundamental and will always continue at a faster pace. Whoever gets information faster through interactive control will act more quickly and precisely on that information and will win the competition. The organization's ability to adapt to its environment is determined by its ability to diagnose, respond to, and interactively monitor what happens in its environment through 
an effective learning process. Thus, an organization managed by individuals who work together towards a shared vision, instead of orders will be created. A learning organization is an innovative organization, because organizational learning has a positive relationship with technological innovation which is a multi-dimensional concept, and handles diffusion and application of technology to obtain commercial benefits. In essence, the capability of technological innovation is the way in which an organization can more efficiently select, implement, and use technology than the competitors. Technological innovation refers to the extent to which new products are suitable to target markets and make a set of benefits provided to customers. Innovation in the process is how companies implement unique capabilities to capture their potential market with more unique products. The company targets different products for different types of customers according to their purchasing ability. Achieving innovation requires coordinated efforts from many different actors and the integration of cross-functional activities, knowledge domains, contexts and applications. The organization's ability to innovate is a prerequisite for the successful use of innovative resources and new technologies. With the innovations, it is necessary to know how learning should be done to find information and knowledge to guarantee sustainable innovations. Organizations must develop their abilities to achieve the desired results and important continuous learning for each individual.

\section{Limitations and recommendation for future studies}

This study has limitations, because it uses cross-sectional, so the relationship between the concepts tested in this study is a brief description at a certain time. Of course, to have further implications for firm performance, longitudinal studies are proposed for future research to assess the results of long-term human resource development to improve company performance.

The study is limited to firm performance and not the concept of competitive advantage. In future research, the variable of competitive advantage is recommended. Research using an interactive control capability proposition can also be carried out to other industries, such as the metal industry in Klaten, batik industry in Pekalongancoastal area and industries in Jogya and Solo that are rich of the royal cultural values.

\section{References}

Abernethy, M. A., \& Brownell, P. (1999). The role of budgets in organizations facing strategic change: an exploratory study. Accounting, Organizations and Society, 24(3), 189-204.

Adel Ismail, A.-A., Nayla Yousif, A.-M., \& Yasmeen Fraidoon, M. (2007). Organizational culture and knowledge sharing: critical success factors. Journal of Knowledge Management, 11(2), 22-42.

Archibugi, D., \& Coco, A. (2005). Measuring technological capabilities at the country level: A survey and a menu for choice. Research Policy, 34(2), 175-194.

Argyris, C., \& Schön, D. A. (1978). Organizational Learning: A Theory of Action Perspective, Reading. MA: Addison-Wesley.

Azubuike, V. M. (2013). Technological innovation capability and firm's performance in new product development. Communications of the IIMA, 13(1), 4.

Baker, W., \& Sinkula, J. (1990). The synergistic effect of market orientation and learning orientation on organizational performance. Journal of the Academy of Marketing Science, 27(4), 411-427.

Barney, J. (1991). Firm Resources and sustained competitive advantage. Journal of Management, 17(1), 99-120.

Bedford, T., Riley, S., Barr, I. G., Broor, S., Chadha, M., Cox, N. J., Daniels, R. S., Gunasekaran, C. P., Hurt, A. C., \& Kelso, A. (2015). Global circulation patterns of seasonal influenza viruses vary with antigenic drift. Nature, 523(7559), 217.

Bisbe, J., \& Otley, D. 2004. The effects of the interactive use of management control systems on product innovation. Accounting, Organizations and Society, 29(8), 709-737.

Burgelman, R. A., Christensen, C. M., \& Wheelwright, S. C. (2004). Strategic management of technology and innovation. McGraw-Hill.

Carlsson, B., \& Stankiewicz, R. (1991). On the nature, function and composition of technological systems. Journal of evolutionary economics, 1(2), 93-118.

Chen, J., \& Sun, X.-h. 2009. The relationship research among organizational commitment, employee satisfaction and work performance. Paper presented at the Management Science and Engineering, 2009. ICMSE 2009.

Crossan, M. M., Lane, H. W., White, R. E., \& Djurfeldt, L. (1995). Organizational learning: Dimensions for a theory. The International Journal of Organizational Analysis, 3(4), 337-360.

Curado, A. (2006). Organisational learning and organisational design. The Learning Organization, 13(1), 25-48.

Darroch, J., \& McNaughton, R. (2003). Beyond market orientation: Knowledge management and the innovativeness of New Zealand firms. European Journal of Marketing, 37(3/4), 572-593.

Davidsson, P., \& Honig, B. (2003). The role of social and human capital among nascent entrepreneurs. Journal of business venturing, 18(3), 301-331.

Dibella, A. J., Nevis, Edwin C, \& Gould, J. M. (1996). Understanding organizational learning capability. Journal of Management Studies, 33(3), 361-379.

Fiol, C. M., \& Lyles, M. A. (1985). Organizational learning. Academy of Management. The Academy of Management Review (pre-1986), 10(000004), 803.

García-López, J. M., Jenei, T., Chope, K., \& Bubeck, K. A. (2010). Diagnosis and management of cranial and caudal nuchal bursitis in four horses. Journal of the American Veterinary Medical Association, 237(7), 823-829.

Grafton, J., Lillis, A. M., \& Widener, S. K. (2010). The role of performance measurement and evaluation in building organizational capabilities and performance. Accounting, Organizations and Society, 35(7), 689-706.

Grant Keeble, K. (2009). Construction process improvement through cognitive power under team generative learning. Engineering, Construction and Architectural Management, 16(4), 307-324.

Grant, R. M. (1998). The resource-based theory of competitive advantage: Implications for strategy formulation. California Management Review, Spring, 114-135.

Hair, J. F. J., Anderson, R. E., Tatham, R. L., \& Black, W. C. (1998). Multivariate Data Analysis, $5^{\text {th }}$ ed., Prentice Hall.

Hamel, G., \& Prahalad, C. (1990). The core competence of the corporation. Harvard Business Review, 68, 79-91. 
Helfat, C. E., \& Peteraf, M. A. (2003). The dynamic resource-based view: Capability lifecycles. Strategic Management Journal, 24(10), 997-1010.

Henri, J.-F. (2006). Management control systems and strategy: A resource-based perspective. Accounting, organizations and society, 31(6), $529-558$.

Hurley, R. F., \& Hult, G. T. M. (1998). Innovation, market orientation, and organizational learning: An integration and empirical examination. Journal of Marketing, 62(3), 42-54.

Ireland, R. D., Hitt, M. A., Camp, S. M., \& Sexton, D. L. (2001). Integrating entrepreneurship and strategic management actions to create firm wealth. Academy of Management Perspectives, 15(1), 49-63.

Jong-Wook, K., Price, J. L., \& Mueller, C. W. (1997). Assessment of Meyer and Allen's three-component model of organizational commitment in South Korea. Journal of Applied Psychology, 8(26), 961-973.

Kaptijn, R. (2009). Assessing affective commitment in the three-component model and the two factor theory: a comparison between the theories of meyer and allen and herzberg, mausner and snyderman. University of Twente.

Kloot, L. (1997). Organizational learning and management control systems: responding to environmental change. Management Accounting Research, 8(1), 47-73.

Lemon, M., \& Sahota, P. S. (2004). Organizational culture as a knowledge repository for increased innovative capacity. T echnovation, 24(6), 483-499.

Liao, S.-H., \& Wu, C.-c. (2010). System perspective of knowledge management, organizational learning, and organizational innovation. Expert systems with Applications, 37(2), 1096-1103.

Mahoney, J. T., \& Pandian, J. R. (1992). The resource-based view within the conversation of strategic management. Strategic Management Journal, 13(5), 363-380.

Marquarnt, M. J. (1996). Building the Learning Organization. Mc.Graw-Hill, New York Companies, Inc.

McAdam, R., McConvery, T., \& Armstrong, G. (2004). Barriers to innovation within small firms in a peripheral location. International Journal of Entrepreneurial Behavior \& Research, 10(3), 206-221.

Meyer, J. P., Becker, T. E., \& Van Dick, R. (2006). Social identities and commitments at work: Toward an integrative model. Journal of Organizational Behavior: The International Journal of Industrial, Occupational and Organizational Psychology and Behavior, 27(5), 665-683.

Moorman, C. (1995). Organizational market information processes: Cultural antecedents and new product outcomes. Journal of Marketing Research, 32(3), 318-335.

Mowday, R. T., Porter, L. W., \& Steers R.M. (1982). Employee-Organization Linkages: The Psychology of Commitment, Absenteeism and Turnover. New York: Academic Press.

Naranjo-Gil, D., \& Hartmann, F. (2007). Management accounting systems, top management team heterogeneity and strategic change. Accounting, Organizations and Society, 32(7-8), 735-756.

Ordóñez de Pablos, P., \& Lytras, M. D. (2008). Competencies and human resource management: implications for organizational competitive advantage. Journal of Knowledge Management, 12(6), 48-55.

Osborn, C. S. (1998). Systems for sustainable organizations: emergent strategies, interactive controls and semi-formal information. Journal of Management Studies, 35(4), 481-509.

Parkman, I. D., Holloway, S. S., \& Sebastiao, H. (2012). Creative industries: aligning entrepreneurial orientation and innovation capacity. Journal of Research in Marketing and Entrepreneurship, 14(1), 95-114.

Peteraf, M. A., \& Barney, J. B. (2003). Unraveling the resource-based tangle. Managerial and Decision Economics, 24(4), 309-323.

Robbins. (2009). Organizational behavior. Salemba Empat, Jakarta.

Shurafa, R., \& Mohamed, R. B. (2016). Management control system, organizational learning, and firm's performance: An empirical study from developing economy. International Journal of Advanced and Applied Sciences, 3(10), 79-88.

Simons, R. (1990). The role of management control systems in creating competitive advantage: new perspectives, Readings in accounting for management control: 622-645: Springer.

Simons, R. (1991). Strategic orientation and top management attention to control systems. Strategic Management Journal, 12(1), 49-62.

Simons, R. (1994a). How new top managers use control systems as levers of strategic renewal. Strategic management journal, 15(3), 169189.

Simons, R. (1994b). Levers of control: How managers use innovative control systems to drive strategic renewal: Harvard Business Press.

Simons, R., Dávila, A., \& Kaplan, R. S. (2000). Performance measurement \& control systems for implementing strategy: Prentice Hall.

Slater, S. F., \& Narver, J. C. (1995). Market orientation and the learning organization. Journal of Marketing, 59(3), 63-74.

Song, M., Droge, C., Hanvanich, S., \& Calantone, R. (2005). Marketing and technology resource complementarity: An analysis of their interaction effect in two environmental contexts. Strategic Management Journal, 26(3), 259-276.

Tani, T. (1995). Interactive control in target cost management. Management Accounting Research, 6(4), 399-414.

Tippins, M. J., \& Sohi, R. S. (2003). IT competency and firm performance: is organizational learning a missing link? Strategic Management Journal, 24(8), 745-761.

Tuomela, T.-S. (2005). The interplay of different levers of control: A case study of introducing a new performance measurement system. Management Accounting Research, 16(3), 293-320.

Walsh, S., \& Linton, J. D. (2002). The measurement of technical competencies. The Journal of High technology management research, 13(1), 63-86.

Widener, S. K. (2007). An empirical analysis of the levers of control framework. Accounting, organizations and society, 32(7-8), 757-788.

Yam, R. C., Guan, J. C., Pun, K. F., \& Tang, E. P. (2004). An audit of technological innovation capabilities in Chinese firms: some empirical findings in Beijing, China. Research policy, 33(8), 1123-1140.

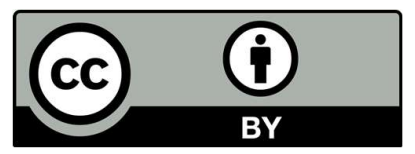

(C) 2020 by the authors; licensee Growing Science, Canada. This is an open access article distributed under the terms and conditions of the Creative Commons Attribution (CC-BY) license (http://creativecommons.org/licenses/by/4.0/). 